\title{
EVALUASI KURIKULUM PELATIHAN PENYUSUNAN RENSTRA KEMENTERIAN ESDM BERDASARKAN KEBUTUHAN DAN HARAPAN ALUMNI PELATIHAN di PPSDMA
}

\author{
Ahmad Helmi \\ Pusat Pengembangan Sumber Daya Manusia Aparatur KESDM
}

\begin{abstract}
ABSTRAK
Tujuan penelitian ini adalah untuk menganalisis harapan dan kebutuhan peserta pelatihan, menganalisis tingkat hubungan masing-masing harapan dan kebutuhan serta rumusan perbaikan untuk meningkatkan mutu kurikulum Pelatihan Penyusunan Renstra Kementerian ESDM, dan merumuskan rekomendasi perbaikan untuk pengembangan kurikulum Pelatihan Penyusunan Renstra Kementerian ESDM. Adapun data penelitian digali dengan teknik studi literatur, penyebaran kuesioner dan wawancara. Informan penelitian adalah alumni pelatihan penyusunan renstra Kementerian ESDM dan widyaiswara PPSDM Aparatur (ahli kurikulum dan substansi pelatihan renstra). Analisis data menggunakan analisis model interaktif. Hasil penelitian ini yaitu, di dapatkannya informasi harapan dan kebutuhan peserta pelatihan, analisis tingkat hubungan masing-masing harapan dan kebutuhan peserta pelatihan Penyusunan Renstra Kementerian ESDM dan rumusan perbaikan, serta rekomendasi perbaikan untuk pengembangan kurikulum Pelatihan PEnyusunan Renstra Kementerian ESDM.
\end{abstract}

Kata kunci : evaluasi kurikulum; pelatihan; renstra; pengembangan kurikulum.

\section{ABSTRACT}

The purpose of this study is to analyze the expectations and needs of training participants, to analyze the level of relationship of each expectation and need and formulation of improvements to improve the quality of the curriculum for the ESDM Ministry's Strategic Planning Training, and to formulate improvement recommendations for the curriculum development of the ESDM Ministry's Strategic Planning Drafting Training. The research data was extracted with literature study techniques, questionnaires and interviews. Research informants are alumni of the ESDM Ministry's strategic planning training and Trainers of PPSDM Aparatur (curriculum experts and strategic training substance). Data analysis uses interactive model analysis. The results of this study are information on the expectations and needs of training participants, an analysis of the level of relationship of each expectation and needs of trainees in the ESDM Ministry's Strategic Planning and its improvements formula, and improvement recommendations for curriculum development of the ESDM Ministry's Strategic Planning.

Keywords: Curriculum evaluation; training; Strategic Planning; Curriculum Development

\section{PENDAHULUAN}

Evaluasi kurikulum merupakan komponen yang perlu dikuasai untuk melaksanakan kurikulum. (Ibrahim dan Masitoh, 2011: 108). Tujuan dari evaluasi kurikulum adalah perbaikan program pelatihan, pertanggungjawaban pada berbagai pihak, penentuan tindak lanjut hasil pengembangan. Caracelli (2006); menjelaskan bahwa evaluasi kurikulum bertujuan untuk:: pengembangan (development purpose), pertanggungjawaban (accountability purpose) dan pengetahuan (knowledge purposes).

Terkait evaluasi kurikulum, menurut $\mathrm{Al}$ Musanna, (2012), bahwa pengukuran (measurement) lebih menekankan pada kuantitas atau membandingkan antara idealitas dan realitas, atau membandingkan tujuan dengan capaian akhir sebuah proses. Sedangkan asesmen (assessment) dalam pandangan teoretisi evaluasi berada pada posisi antara pengukuran dan evaluasi, pertanggungjawaban (accountability). Pertanggungjawaban berkenaan dengan laporan sejauhmana keberhasilan atau kegagalan pencapaian sasaran yang ditentukan atau efektivitas program, tes (test), penilaian hasil belajar dan penelitian.

Konsep evaluasi kurikulum menurut Ibrahim dan Masitoh, (2011:110) meliputi pengukuran (measurement), mengkaji (congruence) menghubungkan kegiatan evaluasi dengan tujuan mengkaji efektifitas kurikulum yang sedang dikembangkan.

Evaluasi kurikulum tidak sepantasnya dimaknai sebatas pengukuran efektifitas dan efesiensi pembelajaran tetapi juga harus ditempatkan 
sebagai bagian dari mekanisme proses pertanggungjawaban publik mengenai eksistensi dan kebermaknaan kurikulum yang berlaku dalam mempersiapkan sumber daya manusia yang mumpuni dalam menjawab kebutuhan organisasi.

Pelatihan Penyusunan Perencanaan Strategis (Renstra) Kementerian ESDM merupakan program baru yang dilaksanakan Badan Pengembangan SDM ESDM berkolaborasi dengan pemangku kepentingan utama khususnya Biro Perencanaan Kementerian ESDM. Pasca pelaksanaan pelatihan tersebut, banyak masukan dari alumni peserta pelatihan dalam rangka meningkatkan mutu program ini melalui pengembangan kurikulum nya. Dalam konteks siklus sistem pelatihan, evalusi pelaksanaan pelatihan menggunakan perspekif alumni peserta pelatihan menjadi bagian sangat penting sebagai dasar bagi penyelenggara pelatihan untuk memperbaiki kurikulum pelatihan.

Kurikulum adalah dokumen yang berisi panduan untuk menjalankan program pelatihan agar tujuan pelatihan tercapai. Dilihat dari aspek komponen kurikulum, para ahli sepakat bahwa pengembangan kurikulum merupakan proses pengembangan terhadap komponen-komponen tersebut. Namun demikian, tidak ada kesepakatan mengenai jumlah komponen dan nama-nama komponen tersebut. Ralp Tyler dalam Zuhdi $(2011,87)$ mengemukakan empat komponen, yaitu tujuan, pengalaman (materi), organisasi dan evaluasi. Ornstein dan Hunkins menyatakan, "tiga komponen yang perlu diperhatikan dalam pengembangan kurikulum, yaitu materi (content), pengalaman belajar (experiences), dan lingkungan belajar (educational environments), (Ornstein, 1993:212). Sedangkan Zais (1976,297) menggunakan istilah anatomi kurikulum yang mencakup: tujuan (aims, goals, objective); isi materi (content); kegiatan belajar (learning activities); dan evaluasi (evaluation). Komponen tujuan dalam kurikulum sangat penting untuk mengukur sejauhmana ketercapaian peserta didik menguasai materi pembelajaran yang telah diajarkan. Tanpa mengetahui apa tujuan pelatihan maka akan menyulitkan bagi lembaga pelatihan dan peserta pelatihan untuk mengevaluasi keberhasilan pelatihan. Dengan demikian, setiap kurikulum wajib menetapkan tujuan pembelajaran tentang apa yang ingin dicapai oleh peserta pelatihan atau lembaga pelatihannya. Isi atau materi merupakan pengalaman dan kegiatan yang dikembangkan dan disusun menjadi alat mencapai tujuan pendidikan. Antara materi dengan komponen yang lain sangat berkaitan. Materi yang diajarkan harus mengacu pada tujuan pendidikan. Brady menegaskan bahwa, "isi kurikulum dapat didefenisikan pada dua poin penting; pertama isi kurikulum dapat dimaknai sebagai mata pelajaran dalam proses belajar mengajar yang termasuk didalamnya beberapa informasi faktual, pengetahuan, keahlian, konsep, sikap dan nilai kedua isi kurikulum adalah sesuatu yang penting dalam proses belajar mengajar dimana dua elemen pokok kurikulum yang termuat didalamnya adalah isi dan metode dalam interaksi yang tetap" (Brady,1992:102). Zais (1976:324). menambahkan bahwa isi kurikulum biasanya terdiri atas tiga elemen yaitu pengetahuan, proses dan nilai. Isi atau materi yang akan diajarkan di sekolah dapat dipilih melalui kriteria di bawah ini dengan mempertimbangkan hal sebagai berikut: a) harus sesuai dengan tujuan yang ingin dicapai, b) sesuai dengan perkembangan peserta didik, c) bermanfaat bagi peserta didik, masyarakat, bangsa dan negara sekarang atau masa depan d) sesuai dengan perkembangan ilmu pengetahuan dan teknologi (Zuhdi:2011,90). Sedangkan menurut Print $(1993,145)$, setidaknya ada beberapa kriteria yang harus diperhatikan dalam pemilihan isi kurikulum, yaitu: 1) Materi sangat signifikan (Significance); 2) Materi memiliki tingkat validitas yang tinggi (validity); 3) Materi hendaknya memiliki relevansi dengan kehidupan dan tuntutan sosial (Social relevance); 4) Materi berguna bagi peserta didik secara individual (Utility); 5)Materi dapat dipelajari oleh peserta didik (Learnability); dan 6) Materi menarik perhatian peserta didik (Interest).

Dalam konteks siklus sistem pelatihan, evalusi pelaksanaan pelatihan menggunakan perspekif alumni peserta pelatihan menjadi bagian sangat penting untuk memberikan dasar bagi penyelenggaran pelatihan memperbaiki kurikulumnya.

Pelaksanaan Pelatihan Penyusunan Rencana Strategis (Renstra) Kementerian Energi dan Sumber Daya Mineral di Pusat Pengembangan Sumber Daya Manusia Aparatur (PPSDMA) sudah selesai dilakukan. Evaluasi selanjutnya atas pelatihan menunjukan bahwa hasil pelatihan belum sesuai dengan hasil yang diharapkan. Oleh karena itu perlu dilakukan evaluasi kurikulum pelatihan penyusunan renstra Kementerian ESDM berdasarkan kebutuhan dan harapan alumni pelatihan.

\section{TINJAUAN TEORI \\ 1. Pelatihan}

Osborne (1996) mengartikan pelatihan sebagai suatu proses yang terencana untuk memo- 
difikasi sikap, pengetahuan atau keterampilan melalui pengalaman belajar guna mencapai kinerja yang efektif pada satu atau sejumlah aktivitas. Oemar Hamalik (2000) menjelaskan bahwa pelatihan (training) adalah proses menggunakan berbagai teknik untuk mengubah sikap, pengetahuan dan keterampilan guna mencapai perilaku yang efektif dalam melaksanakan tugas. Sedangkan, H.H. McAshan (1981) membedakan pendidikan dan pelatihan atas dasar orientasinya. Pendidikan berorientasi pada konten, sedangkan pelatihan berorientasi pada pekerjaan.

Goldstsein dan Gressner (1988) dalam Kamil (2010, hlm. 6) mendefinisikan pelatihan sebagai usaha sistematis untuk menguasai keterampilan, peraturan, konsep, ataupun cara berperilaku yang berdampak pada peningkatan kinerja. Selanjutnya menurut Dearden (1984) dalam Kamil (2010, hlm.7) yang menyatakan bahwa pelatihan pada dasarnya meliputi proses belajar mengajar dan latihan bertujuan untuk mencapai tingkatan kompetensi tertentu atau efisiensi kerja. Sebagai hasil pelatihan, peserta diharapkan mampu merespon dengan tepat dan sesuai situasi tertentu. Selanjutnya Fiedman dan Yarbrough dalam Sudjana (2007, hlm.4) menunjukan bahwa pelatihan adalah upaya pembelajaran, yang diselenggarakan oleh organisasi (instansi pemerintah, lembaga swadaya masyarakat, perusahaan, dan lain sebagainya) untuk memenuhi kebutuhan atau untuk mencapai tujuan organisasi.

Sebuah pelatihan idealnya dirancang untuk mewujudkan tujuan-tujuan, baik tujuan organisasi yang menyelenggarakan pelatihan maupun tujuan para peserta yang mengikuti pelatihan secara perorangan. Karena tujuan penelitian tidak hanya meningkatkan pengetahuan dan keterampilan saja, melainkan juga untuk mengembangankan bakat. Moekijat (1992, hlm.2) menyebutkan bahwa tujuan pelatihan adalah untuk : 1) Mengembangkan keahlian, sehingga pekerjaan dapat diselesaikan dengan lebih cepat dan lebih efektif; 2) Mengembangkan pengetahuan, sehingga pekerjaan dapat dikerjakan secara rasional; dan 3) Mengembangkan sikap, sehingga menimbulkan kemampuan kerjasama dengan teman-teman pegawai dan dengan pimpinan. Mills dalam Artasasmita (1987, hlm.20) menyatakan bahwa tujuan pelatihan adalah Untuk menolong peserta pelatihan agar memperoleh keterampilan, sikap, dan kebiasaan berfikir dengan efisien dan efektif.

Pengertian tujuan pelatihan tersebut jelas mengungkapkan bahwa pelatihan haruslah menjadi sarana pemenuh kebutuhan peserta pelatihan untuk dapat mengembangkan keteram- pilan, pengetahuan, sikap yang dapat dimanfaatkan oleh peserta pelatihan setelah mengikuti pelatihan tersebut sesuai dengan kompetensinya sebagai upaya pengembangan usaha. Secara khusus dalam kaitan dengan pekerjaan, Simamora dalam Kamil (2010, hlm. 11) mengelompokan tujuan pelatihan ke dalam lima bidang, yaitu: a. Memutakhirkan keahlian para karyawan sejalan dengan perubahan teknologi. Melalui pelatihan, pelatih memastikan bahwa karyawan dapat secara efektif menggunakan teknologi-teknologi baru. b. Mengurangi waktu belajar bagi karyawan untuk menjadi kompeten dalam pekerjaan. c. Membantu memecahkan permasalahan operasional. d. Mempersiapkan karyawan untuk promosi, dan e. Mengorientasikan karyawan terhadap organisasi.

Model sistem diklat yang digunakan yaitu model generik sistem diklat ADDIE (analysis, design, develop, implement, dan evaluate) seperti disajikan pada Gambar 1.

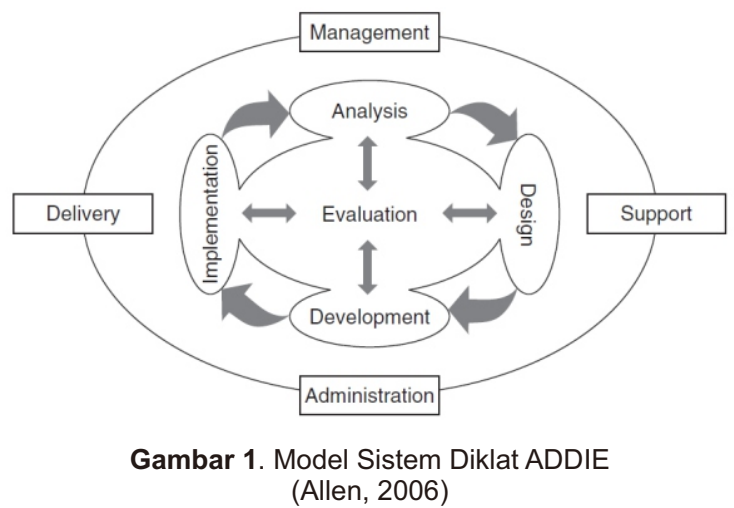

Untuk mengetahui ketercapaian tujuan dari pelatihan, maka perlu dilakukan evaluasi yang melibatkan peserta pelatihan dan pengajar. Hal ini dilakukan untuk mengetahui apakah kurikulum pelatihan tersebut sudah sesuai dengan harapan dan kebutuhan peserta.

\section{Evaluasi Kurikulum \\ Pengertian Evaluasi}

Evaluasi merupakan bagian dari sistem manajemen. Menurut Linderman (2007), secara umum sistem manajemen mencakup empat bagian yaitu 1. Perencanaan, 2. Pengorganisasian, 3. Pelaksanaan, dan 4. Evaluasi.

Perencanaan merupakan proses yang mendahului pengambilan keputusan (Robbins, et al., 2010).

Pengorganisasian adalah penyusunan struktur organisasi yang sesuai dengan tujuan organisasi, sumber daya yang dimilikinya dan lingkungan yang melingkupinya (Handoko, 2003). 
Pelaksanaan merupakan sistem kerjasama sekelompok orang, yang dilakukan dengan pembidangan dan pembagian seluruh pekerjaan atau tugas dengan membentuk sejumlah satuan atau unit kerja, yang menghimpun pekerjaan sejenis dalam satu-satuan kerja. Kemudian dilanjutkan dengan menetapkan wewenang dan tanggungjawab masing-masing dengan mengatur hubungan kerja baik secara vertikal maupun horizontal (De Bruyn, Lilien, 2008).

Evaluasi merupakan kegiatan yang membandingkan antara hasil implementasi dengan kriteria dan standar yang telah ditetapkan untuk melihat keberhasilannya. Dari evaluasi kemudian akan tersedia informasi mengenai sejauh mana suatu kegiatan tertentu telah dicapai sehingga bisa diketahui bila terdapat perbedaan antara rencana yang telah ditetapkan dengan hasil yang bisa dicapai. Setiap program, kegiatan atau aktivitas yang direncanakan selalu diakhiri dengan suatu evaluasi (Linderman, 2007). Evaluasi dimaksudkan untuk melihat kembali apakah suatu program atau kegiatan telah sesuai dengan perencanaan atau belum (Sukmadinata, 2008).

\section{Pengertian Evaluasi Kurikulum}

Caswel \& Campbell (1935) dalam Majid (2014) mendefinisikan kurikulum sebagai: "to be composed of all experiences children have under the guidance of teacher". Kurikulum berisi seperangkat rencana berisi pengalaman yang akan dimiliki siswa di bawah bimbingan guru. Kurikulum yang dirancang merupakan satu set rencana yang berisi pengalaman yang akan dimiliki siswa selama mengikuti program pendidikan. Pengalaman siswa dalam serangkaian kegiatan pembelajaran berada di bawah bimbingan guru. Guru bertanggung jawab dalam membimbing siswa selama proses pembelajaran dalam mengimplementasi sebuah kurikulum.

Dapat diartikan bahwa kurikulum adalah semua rencana pembelajaran yang menjadi tanggung jawab sekolah dan juga pengalaman yang diberikan kepada siswa dalam belajar sehingga mereka dapat mencapai keterampilan umum dan pengetahuan di berbagai materi pembelajaran.

Pengertian yang serupa dijelaskan dalam Undang-Undang nomor 20 tahun 2003 dan Peraturan Pemerintah nomor 19 tahun 2005 menetapkan pengertian kurikulum sebagai: seperangkat rencana dan pengaturan mengenai tujuan, isi, dan bahan pelajaran serta cara yang digunakan sebagai pedoman penyelenggaraan kegiatan pembelajaran untuk mencapai tujuan pendidikan tertentu. Kurikulum berisi perencanaan dan pengaturan yang berisi tujuan, bahan ajar, cara yang ditempuh untuk mencapai tujuan yang digunakan sebagai pedoman pembelajaran. Berdasarkan beberapa pengertian di atas, dapat disimpulkan bahwa kurikulum merupakan rencana/program kegiatan pembelajaran yang berisi tujuan, isi, dan bahan/materi pelajaran yang akan memberikan pengalaman belajar bagi siswa, memberikan bekal keterampilan umum dan pengetahuan untuk mencapai tujuan pendidikan tertentu.

\section{Konsep Evaluasi Kurikulum}

Evaluasi kurikulum memegang peranan penting baik dalam penentuan kebijakan pendidikan umumnya maupun pada tingkat pengambilan keputusan dalam kurikulum. Hasil-hasil evaluasi kurikulum dapat digunakan oleh para pemegang kebijakan pendidikan dan para pengembang kurikulum dalam memilih dan menetapkan kebijakan pengembangan model kurikulum dan pendekatan yang digunakan. Tanpa evaluasi, maka tidak akan diketahui bagaimana kondisi kurikulum tersebut dalam rancangan, pelaksanaan serta hasilnya (Cronholm dan Goldkuhl, 2003).

Dari konsep evaluasi kurikulum di atas, jelas bahwa evaluasi kurikulum dimaksudkan sebagai suatu proses mempertimbangkan untuk memberi nilai dan arti terhadap suatu kurikulum pendidikan dan pelatihan tertentu. Dengan demikian evaluasi kurikulum adalah proses penerapan prosedur ilmiah untuk mengumpulkan data yang valid dan untuk membuat keputusan tentang kurikulum pendidikan dan pelatihan yang sedang berjalan atau telah dijalankan.

Evaluasi kurikulum minimal terfokus pada empat bidang; yaitu evaluasi terhadap penggunaan kurikulum, desain kurikulum (curriculum design), hasil dari peserta didik, liable kurikulum. Dengan kata lain, liable evaluasi kurikulum dapat dilakukan pada hasil (outcome) dari kurikulum tersebut (outcomes based evaluation) dan juga dapat pada komponen kurikulum tersebut (intrinsic evaluation). Outcomes based evaluation merupakan liable evaluasi kurikulum yang paling sering dilakukan (Worthen, Sanders. 1981).

Evaluasi kurikulum akan memberikan informasi penting bagi perancang dan pengembang kurikulum menyangkut kelemahan dan kekuatan sebuah kurikulum yang telah dirancang dan diimplementasikan dan akan berguna untuk pengembangan dan perubahan kurikulum di masa yang akan datang sekaligus sebagai tolak ukur keberhasilan pendidikan Indonesia dalam menciptakan manusia Indonesia yang bermutu dan 
berdaya saing dalam persaingan global (Yunus, 2010).

\section{Peranan Evaluasi Kurikulum}

Sukmadinata (2012) menyampaikan bahwa peranan evaluasi kebijaksanaan dalam kurikulum khususnya pendidikan umumnya minimal berkenaan dengan 3 (tiga) hal yaitu:

- evaluasi sebagai moral judgement, konsep utama dalam evaluasi adalah masalah nilai, hasil dari suatu evaluasi berisi suatu nilai yang akan digunakan untuk tindakan selanjutnya hal ini mengandung 2 pengertian, (1) evaluasi berisi suatu skala nilai moral,berdasarkan skala tersebut suatu objek evaluasi dapat dinilai, (2) evaluasi berisi suatu perangkat kriteria praktis berdasarkan kriteria-kriteria suatu hasil dapat dinilai

- evaluasi dan penentuan keputusan, pengambilan keputusan dalam pelaksanaan pendidikan atau kurikulum banyak yaitu : guru, murid, orang tua, kepala sekolah, para inspektur, pengembangan kurikulum dan lain lain, beberapa diantara mereka yang memegang peranan paling besar dalam penentuan keputusan.pada prinsipnya tiap individu diatas membuat keputusan sesuai dengan posisinya.

- evaluasi dan konsesus nilai dalam berbagai situasi pendidikan serta kegiatan pelaksanaan evaluasi kurikulum sejumlah nilai-nilai dibawakan oleh orang-orang yang ikut terlibat dalam kegiatan penilaian atau evaluasi, para partisipan dalam evaluasi pendidikan dapat terdiri dari : orang tua, murid, guru, pengembang kurikulum, administrator, ahli politik, ahli ekonomi, penerbit, arsitek dan lain sebagainya. Bagaimana caranya agar diantara mereka terdapat kesatuan penilaian hanya dapat di capai melalui suatu konsensus. Secara historis konsensus nilai dalam evaluasi kurikulum berasal dari tradisi tes mental serta eksperimen.

\section{Pentingnya Evaluasi Kurikulum}

Evaluasi kurikulum dapat menyajikan informasi mengenai kesesuaian, efektifitas dan efisiensi kurikulum tersebut terhadap tujuan yang ingin dicapai dan penggunaan sumber daya, yang mana informasi ini sangat berguna sebagai bahan pembuat keputusan apakah kurikulum tersebut masih dijalankan tetapi perlu revisi atau kurikulum tersebut harus diganti dengan kurikulum yang baru. Evaluasi kurikulum juga penting dilakukan dalam rangka penyesuaian dengan perkembangan ilmu pengetahuan, kemajuan teknologi dan kebutuhan pasar yang berubah. Evaluasi kurikulum dapat menyajikan bahan informasi mengenai area-area kelemahan kurikulum sehingga dari hasil evaluasi dapat dilakukan proses perbaikan menuju yang lebih baik. Evaluasi ini dikenal dengan evaluasi formatif. Evaluasi ini biasanya dilakukan waktu proses berjalan. Evaluasi kurikulum juga dapat menilai kebaikan kurikulum apakah kurikulum tersebut masih tetap dilaksanakan atau tidak, yang dikenal evaluasi sumatif(Sukmadinata, 1997).

\section{Masalah Dalam Evaluasi Kurikulum}

a) Dasar teori yang digunakan dalam evaluasi kurikulum lemah.

b) Intervensi Pendidikan yang dilakukan tidak memungkinkan dilakukan Blended.

c) Kesulitan dalam melakukan metode randomisasi.

d) Kesulitan dalam menstandarkan intervensi yang dilakukan/kesulitian dalam menseragamkan intervensi.

e) Masalah etika penelitian.

f) Tidak adanya pure outcome.

g) Kesulitan mencari alat ukur.

h) Penggunaan perspektif kurikulum yang berbeda sebagai pembanding.

\section{Tujuan Evaluasi Kurikulum}

Evaluasi kurikulum dapat digunakan untuk (Ibrahim dan Masitoh, 2011):

a) Perbaikan Program, dalam konteks tujuan ini peranan evaluasi lebih bersifat konstruktif, karena informasi hasil evaluasi dijadikan input bagi perbaikan yang diperlukan di dalam program kurikulum yang sedang dikembangkan. Disini evaluasi lebih merupakan kebutuhan yang datang dari dalam sistem itu sendiri karena evaluasi itu dipandang sebagai faktor yang memungkinkan dicapainya hasil pengembangan yang optimal dari sistem yang bersangkutan.

b) Pertanggungjawaban kepada berbagai pihak. Selama dan terutama pada akhir fase pengembangan kurikulum, perlu adanya semacam pertanggungjawaban dari pihak pengembang kurikulum kepada berbagai pihak yang berkepentingan. Pihak-pihak yang dimaksud mencakup baik pihak yang mensponsori kegiatan pengembangan kurikulum tersebut maupun pihak yang akan menjadi konsumen dari kurikulum yang telah dikembangkan.

c) Penentuan tindak lanjut hasil pengembangan. Tindak lanjut hasil pengembangan kurikulum dapat berbentuk jawaban atas dua kemungkinan pertanyaan : Pertama, apakah kurikulum 
baru tersebut akan atau tidak akan disebar luaskan ke dalam sistem yang ada? Kedua, dalam kondisi yang bagaimana dan dengan cara yang bagaimana pula kurikulum baru tersebut akan disebar luaskan ke dalam sistem yang ada? Ditinjau dari proses pengembangan kurikulum yang sudah berjalan, pertanyaan pertama dipandang tidak tepat untuk diajukan pada akhir fase pengembangan.

\section{Model Evaluasi Kurikulum}

Model evaluasi kurikulum secara garis besar dibagi ke dalam empat rumpun model, yaitu measurement, congruence, illumination, dan educational system evaluation (Ibrahim dan Masitoh, 2011).

\section{a) Measurement}

Evaluasi pada dasarnya adalah pengukuran perilaku peserta pelatihan untuk mengungkapkan perbedaan individual maupun kelompok. Hasil evaluasi digunakan terutama untuk keperluan seleksi peserta pelatihan, bimbingan pendidikan dan perbandingan efektifitas antara dua atau lebih program/metode pendidikan. Obyek evaluasi dititik beratkan pada hasil belajar terutama dalam aspek kognitif dan khususnya yang dapat diukur dengan alat evaluasi yang obyektif dan dapat dibakukan. Jenis data yang dikumpulkan dalam evaluasi adalah data obyektif khususnya skor hasil tes.

\section{b) Congruence}

Evaluasi pada dasarnya merupakan pemeriksaan kesesuaian atau congruence antara tujuan pendidikan dan hasil belajar yang dicapai, untuk melihat sejauh mana perubahan hasil pendidikan telah terjadi. Hasil evaluasi diperlukan dalam rangka penyempurnaan program, bimbingan pendidikan dan pemberian informasi kepada pihak-pihak di luar pendidikan. Obyek evaluasi dititik beratkan pada hasil belajar dalam bentuk kognitif, psikomotorik maupun nilai dan sikap. Jenis data yang dikumpulkan adalah data obyektif khususnya skor hasil tes.

c) Illumination

Evaluasi ini pada dasarnya merupakan studi mengenai pelaksanaan program, pengaruh faktor lingkungan, kebaikan-kebaikan dan kelemahan program serta pengaruh program terhadap perkembangan hasil belajar. Evaluasi lebih didasarkan pada judgment (pertimbangan) yang hasilnya diperlukan untuk penyempurnaan program. Obyek evaluasi mencakup latar belakang dan perkembangan program, proses pelaksanaan, hasil belajar dan kesulitan-kesulitan yang dialami. Jenis data yang dikumpulkan pada umumnya data subyektif (judgment data).

\section{d) Educational System Evaluation}

Evaluasi pada dasarnya adalah perbandingan antara performance setiap dimensi program dan kriteria, yang akan berakhir dengan suatu deskripsi dan judgment. Hasil evaluasi diperlukan untuk penyempurnaan program dan penyimpulan hasil program secara keseluruhan. Obyek evaluasi mencakup input (bahan, rencana, peralatan), proses dan hasil yang dicapai dalam arti yang lebih luas. Jenis data yang dikumpulkan meliputi baik data obyektif.

\section{Model Quality Function Deployment}

Model Quality Function Deployment (QFD) adalah salah satu alat pemetaan yang sering digunakan di industri untuk mendesain sebuah produk berdasarkan perspektif harapan dan kebutuhan pelanggan sebagai pengguna produk. Model ini selanjutnya berkembang ke berbagai bidang, salah satunya adalah bidang pendidikan dan pelatihan. Untuk pengembangan kurikulum pendidikan dan pelatihan, QFD telah digunakan oleh para peneliti dan praktisi oleh Martaleo \& Simatupang (2013) untuk mengevaluasi rancangan kurikulum guna penyusunan urutan mata kuliah dan pedoman penyelesaian tugas akhir. Boonyanuwat, Suthummanon, Memongkol, \& Chaiprapat (2008) dalam penelitian untuk mendesain dan mengembangkan kurikulum Program Studi Teknik Industri (TI) di Prince of Songkla University. Aytaç \& Deniz (2005) dalam penelitiannya untuk meninjau dan mengevaluasi kurikulum teknologi roda ban di Tyre Kocaeli University Köseköy Vocational School of Higher Education (KU-KVSHE).

Model generic QFD terkenal dengan sebutan rumah mutu (house of quality) terdiri dari gabungan beberapa matriks seperti disajikan pada Gambar 2. Bagian sisi kiri (A) memuat rangkuman harapan dan keinginan pelanggan yang selanjutnya diterjemahkan oleh tim perancang kurikulum. Terjemahan tim berupa bahasa perbaikan yang bersifat teknis yang dimuat dalam ruang di bawah atap (B). Rumusan perbaikan teknis akan memiliki dampak terhadap harapan pelanggan di mana keterkaitannya dipetakan pada ruang bagian tengah (C). Bentuk hubungan keterkaitan antara perbaikan teknis dan harapan pelanggan dipetakan dan hasilnya berupa nilai kepentingan untuk penentuan prioritas perbaikan yang dimuat dalam bagian D. 


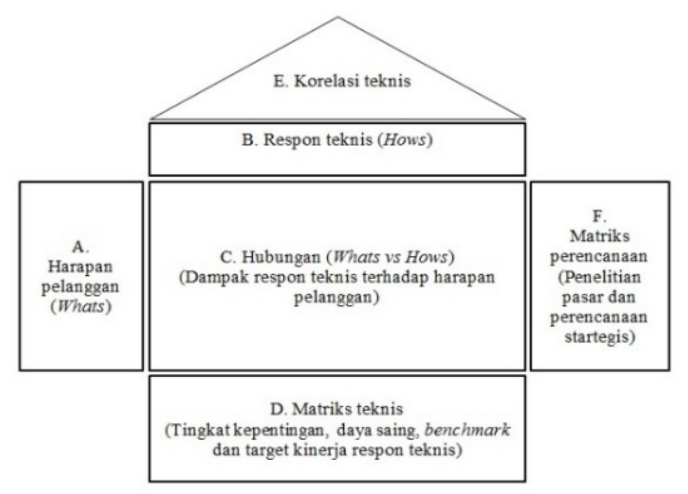

Gambar 2. Matriks rumah mutu (Cohen, 1995).

\section{Metode Penelitian}

\section{Teknik Pengumpulan dan Analisis Data}

Penelitian ini adalah penelitian diskriptif kualitatif - kuantitatif (mixed methods), menurut Cavaye (1996) dalam suatu penelitian studi kasus dapat menggabungkan dua metode (mixed method), sebuah studi kasus dapat melakukan analisis kualitatif terhadap isu-isu spesifik yang kemudian dapat dijadikan variabel terukur dan selanjutnya dianalisis secara kuantitatif.

Penelitian ini dilakukan pada penyelenggaraan Pelatihan Penyusunan Renstra Kementerian ESDM yang diselenggarakan oleh Pusat Pengembangan Sumber Daya Manusia Aparatur, Badan Pengembangan Sumber Daya Manusia, Kementerian ESDM.

Untuk memperoleh data yang diperlukan dalam penelitian ini, penulis menggunakan beberapa metode pengumpulan data yang digunakan dalam sebuah proses penelitian. Metode pengumpulan data kualitatif yang penulis pergunakan meliputi tinjauan pustaka, brainstorming, wawancara dan focus group discussion. Instrumen pengumpulan data adalah peneliti sendiri dengan menggunakan panduan pertanyaan untuk mengoptimalkan proses pengumpulan data. Sedangkan teknik pengumpulan data kuantitatif menggunakan survey. Instrumennya adalah kuesioner yang sudah disiapkan.

Teknik analisis data kuantitatif, dimulai dengan pemeriksaan (editing) data yang diperoleh untuk mengetahui kelayakan data, kemudian melakukan coding berdasarkan item pertanyaan pada kuesioner, kemudian proses berikutnya memasukkan data yang sudah dikelompokkan dalam tabel-tabel yang mudah dipahami. Seperti pada contoh tabel 4 .

Teknik analisis data kualitatif, proses pengolahan data diawali dan pembuatan catatan lapangan (tinjauan pustaka, brainstorming, wawancara, focus group discussion). Tahap selanjutnya menganalisis data yang telah dibuat dalam catatan lapangan dengan cara mengorganisasi data, memilihnya menjadi satuan, menemukan hal penting, dan memutuskan bagian yang akan disampaikan.

Dalam penelitian ini analisis data yang digunakan adalah analisis deskriptif yaitu mengungkapkan suatu masalah dan keadaan sebagaimana adanya, sehingga hanya merupakan penyingkapan fakta (Warsito, 1992: 10).

\section{Informan}

Informan penelitian ini adalah alumni peserta Pelatihan Penyusunan Renstra Kementerian ESDM yang diselenggarakan pada 2018 sebanyak 20 orang. Informan lainnya adalah Widyaiswara sebagai ahli dalam bidang pengembangan kurikulum dan pengajar pada pelatihan tersebut.

\section{Tata Laksana}

Tata laksana penelitian ini mengacu pada tahapan yang dikembangkan pada model QFD. Tata laksana dibagi menjadi dua tahapan, yaitu tahapan pertama menganalisis kebutuhan dan harapan peserta Pelatihan Penyusunan Renstra Kementerian ESDM. Tahap kedua merumuskan terjemahan kebutuhan dan harapan pelanggan serta merumuskan rekomendasi untuk pengembangan kurikulum silabus Pelatihan Penyusunan renstra Kementerian ESDM. Alur tata laksana penelitian disajikan seperti pada Gambar 3 .

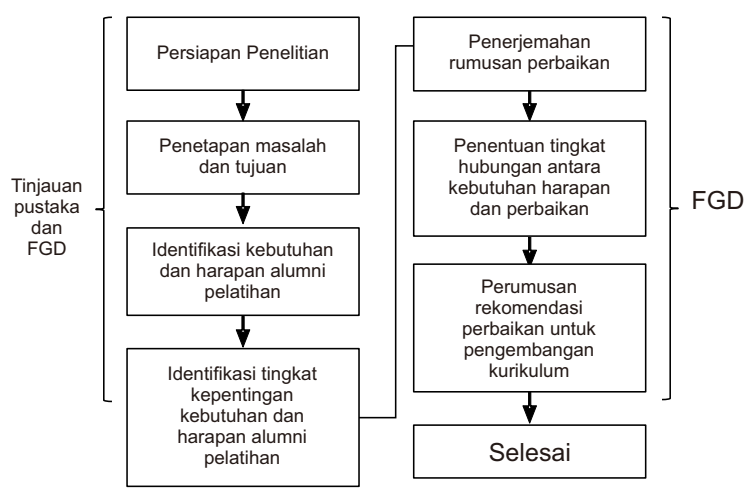

Gambar 3. Alur tata Laksana Penelitian

\section{Hasil dan Pembahasan}

\section{Kurikulum Penyusunan Renstra}

Kurikulum pelatihan Penyusunan Rencana Strategis disiapkan untuk memenuhi kebutuhan penyusunan rencana strategis di lingkungan Kementerian Energi dan Sumber Daya Mineral. Hal ini di lakukan supaya dalam penyusunan Rencana Strategis Kementerian Energi dan Sumber Daya Mineral, bisa lebih optimal dan dapat mengena ke masyarakat melalui program- 
program strategisnya.

Setelah mengikuti pelatihan penyusunan rencana strategis, para peserta diharapkan mampu menyusun rencana strategis Kementerian Energi dan Sumber Daya Mineral. Sedangkan sasaran dari pelatihan penyusunan rencana strategis ini adalah tersedianya pegawai negeri sipil yang memiliki kompetensi teknis menyusun rencana strategis Kementerian ESDM.

Dalam pelatihan penyusunan rencana strategis ini, terdiri atas 8 mata pelatihan, yaitu seperti tertera pada tabel di bawah ini.

\section{Tabel 1}

\begin{tabular}{|c|l|}
\hline No & \multicolumn{1}{|c|}{ MATA PELATIHAN } \\
\hline 1 & Pengantar sistem perencanaan pembangunan nasional \\
\hline 2 & Pengantar kebijakan dan isu strategis sektor ESDM \\
\hline 3 & Asesmen lingkungan strategis organisasi \\
\hline 4 & $\begin{array}{l}\text { Penyusunan visi, misi, tujuan, dan sasarana strategis } \\
\text { jangka menengah }\end{array}$ \\
\hline 5 & $\begin{array}{l}\text { Penyusunan peta strategi berdasarkan konsep } \\
\text { Balanced Scorecard }\end{array}$ \\
\hline 6 & $\begin{array}{l}\text { Penyusunan indikator kinerja dan indikator kinerja } \\
\text { utama }\end{array}$ \\
\hline 7 & Visitasi Penyusunan Renstra pada instansi lain \\
\hline 8 & Penyusunan laporan renstra dan seminar \\
\hline
\end{tabular}

\section{Harapan dan Kebutuhan Alumni Sebagai Pengguna}

Dari hasil pengolahan data kuesioner menggunakan metode kuantitatif, dari peserta dan focus group discussion (fgd) dengan para peserta, dapat disampaikan informasi hasil analisis harapan dan kebutuhan alumni pelatihan penyusunan renstra kementerian ESDM sebagaimana tertera dalam tabel 2, dimana nantinya akan dikelompokkan dalam komponen kurikulum, sebagai berikut:

\section{Tabel 2}

\begin{tabular}{|c|l|}
\hline $\begin{array}{c}\text { Komponen } \\
\text { Kurikulum }\end{array}$ & \multicolumn{1}{c|}{ Harapan dan kebutuhan Alumni } \\
\hline \multirow{2}{*}{ Tujuan } & $\begin{array}{l}\text { Jadwal materi pelatihan tidak sesuai dengan } \\
\text { pelaksanaan }\end{array}$ \\
\cline { 2 - 3 } & $\begin{array}{l}\text { Waktu pelatihan penyusunan renstra dirasa } \\
\text { kurang lama }\end{array}$ \\
\cline { 2 - 3 } & Urutan materi pelatihan agar lebih sistematis \\
\hline \multirow{2}{*}{ Metode } & Perlu studi kasus lebih banyak \\
\cline { 2 - 3 } & Rasio praktek dan teori (70\%; 30\%) \\
\cline { 2 - 3 } & $\begin{array}{l}\text { Mencontohkan langsung bagaimana cara } \\
\text { menyusun dan membuat/ menulis renstra }\end{array}$ \\
\hline \multirow{2}{*}{$\begin{array}{l}\text { Pengajar } \\
\text { dan SDM }\end{array}$} & $\begin{array}{l}\text { Pengajar terkait materi Balance Scorecard } \\
\text { dirasa kurang }\end{array}$ \\
\cline { 2 - 3 } & $\begin{array}{l}\text { Koordinasi panitia saat visitasi harus } \\
\text { diperbaiki }\end{array}$ \\
\hline Fasilitas & Fasilitas penerangan di kamar kurang terang \\
\hline
\end{tabular}

\section{Upaya Perbaikan}

Dari hasil kuesioner dan FGD mengenai harapan dan kebutuhan alumni pelatihan penyusunan renstra tersebut, maka dilakukan konfirmasi melalui wawancara (metode kualitatif), untuk perbaikan nya kepada widyaiswara yang berkompeten di bidang nya yang diwakili oleh tiga (3) orang widyaiswara.

Perbaikan yang didapat untuk menjawab harapan dan kebutuhan alumni diatas, terdapat dua belas (12) perbaikan yang merupakan masukan para widyaiswara yang ahli di bidangnya, dimana setelah ini, hasil tersebut akan dianalisis dengan menggunakan model QFD Evaluasi Kurikulum. Dimana hasil analisis ini untuk menjawab tujuan penelitian yang pertama, yaitu untuk menganalisis harapan dan kebutuhan serta rumusan perbaikan untuk meningkatkan mutu kurikulum Pelatihan Penyusunan Renstra Kementerian ESDM. Hasil konfirmasi kepada 3 orang widyaiswara tersebut disajikan dalam tabel 3 .

\section{Model QFD Evaluasi Kurikulum}

Tahap ini penulis mengidentifikasi atribut suara pelanggan dan diterjemahkan ke dalam karakteristik proses bisnis internal serta di analisis menggunakan matriks hubungan. Hal ini untuk menjawab tujuan penelitian yang kedua yaitu menganalisis tingkat hubungan masing-masing harapan dan kebutuhan serta rumusan perbaikan untuk meningkatkan mutu kurikulum Pelatihan Penyusunan Renstra Kementerian ESDM

Bangunan awal rumah mutu hasil matriks hubungan disajikan pada tabel 4. Ruang suara pelanggan menyajikan hasil identifikasi atribut harapan pelanggan pengguna jasa layanan diklat yaitu Jadwal materi pelatihan tidak sesuai dengan pelaksanaan (A1), Waktu pelatihan penyusunan renstra dirasa kurang lama (A2), Urutan materi pelatihan agar lebih sistematis (A3), Perlu studi kasus lebih banyak (A4), Rasio praktek dan teori (70\%;30\%) (A5), Mencontohkan langsung bagaimana cara menyusun dan membuat / menulis renstra (A6), Pengajar terkait materi Balance Scorecard dirasa kurang (A7), Koordinasi panitia saat visitasi harus diperbaiki (A8), Fasilitas penerangan di kamar kurang terang (A9).

Harapan pelanggan selanjutnya diterjemahkan ke dalam karakteristik proses internal yaitu :

B1 : Review materi terkait dengan Widyaiswara untuk memperoleh jam penyampaian dan kedalaman materi yang sesuai dengan tujuan diklat.

B2 : Penyesuaian dengan kurikulum dan kebutuhan waktu. 
Tabel 3

\begin{tabular}{|c|c|c|}
\hline $\begin{array}{l}\text { Komponen } \\
\text { Kurikulum }\end{array}$ & Harapan dan kebutuhan Alumni & Perbaikan \\
\hline \multirow{3}{*}{ Tujuan } & $\begin{array}{l}\text { Jadwal materi pelatihan tidak sesuai } \\
\text { dengan pelaksanaan }\end{array}$ & \multirow{3}{*}{$\begin{array}{l}\text { - Review materi terkait dengan Widyaiswara untuk memperoleh jam } \\
\text { penyampaian dan kedalaman materi yang sesuai dengan tujuan } \\
\text { diklat. } \\
\text { - Penyesuaian dengan kurikulum dan kebutuhan waktu. } \\
\text { - Sesuaikan dengan urutan mata pelatihan dalam kurikulum }\end{array}$} \\
\hline & $\begin{array}{l}\text { Waktu pelatihan penyusunan renstra } \\
\text { dirasa kurang lama }\end{array}$ & \\
\hline & $\begin{array}{l}\text { Urutan materi pelatihan agar lebih } \\
\text { sistematis }\end{array}$ & \\
\hline \multirow{3}{*}{ Metode } & Perlu studi kasus lebih banyak & \multirow{3}{*}{$\begin{array}{l}\text { - Perkaya referensi kasus } \\
\text { - Gunakan studi kasus yang relevant, agar hasilnya \& waktu lebih } \\
\text { optimal } \\
\text { - Evaluasi efektivitas kegiatan belajar mengajar di dalam kelas }\end{array}$} \\
\hline & Rasio praktek dan teori $(70 \% ; 30 \%)$ & \\
\hline & $\begin{array}{l}\text { Mencontohkan langsung bagaimana cara } \\
\text { menyusun dan membuat/ menulis renstra }\end{array}$ & \\
\hline \multirow[b]{2}{*}{$\begin{array}{l}\text { Pengajar } \\
\text { dan SDM }\end{array}$} & $\begin{array}{l}\text { Pengajar terkait materi Balance } \\
\text { Scorecard (BSC) dirasa kurang }\end{array}$ & \multirow{2}{*}{$\begin{array}{l}\text { - Materi BSC dapat diangkat dalam diklat tersendiri (harus fokus ke } \\
\text { penyusunan peta strategi) } \\
\text { - Peningkatan kompetensi atau manfaatkan praktisi } \\
\text { - Perlu pedoman visitasi dan topik yang sesuai dengan kurikulum } \\
\text { - Peningkatan kompetensi pengelola diklat }\end{array}$} \\
\hline & $\begin{array}{l}\text { Koordinasi panitia saat visitasi harus } \\
\text { diperbaiki }\end{array}$ & \\
\hline Fasilitas & $\begin{array}{l}\text { Fasilitas penerangan di kamar kurang } \\
\text { terang }\end{array}$ & $\begin{array}{l}\text { - Peningkatan / perbaikan fasilitas di kamar } \\
\text { - Sarana prasarana / peralatan disesuaikan kebutuhan proses belajar } \\
\text { mengajar }\end{array}$ \\
\hline
\end{tabular}

B3 : Sesuaikan dengan urutan mata pelatihan dalam kurikulum

B4 : Perkaya referensi kasus

B5 : Gunakan studi kasus yang relevant, agar hasilnya \& waktu lebih optimal

B6 : Evaluasi efektivitas kegiatan belajar mengajar di dalam kelas

B7 : Materi BSC dapat diangkat dalam diklat tersendiri (harus fokus ke penyusunan peta strategi)

B8 : Peningkatan kompetensi atau manfaatkan praktisi

B9: Perlu pedoman visitasi dan topik yang sesuai dengan kurikulum

B10: Peningkatan kompetensi pengelola diklat

B11: Peningkatan/ perbaikan fasilitas di kamar

B12: Sarana prasarana/peralatan disesuaikan

kebutuhan proses belajar mengajar

Untuk memperoleh kepastian nilai dalam perhitungannya, maka dibuat skala nilai sebagai berikut:

$$
\begin{array}{ll}
\varnothing=\text { kosong (tidak ada keterkaitan) } & \rightarrow \text { Nilai : } 0 \\
\text { - = lemah } & \rightarrow \text { Nilai : 1 } \\
\bullet=\text { sedang } & \rightarrow \text { Nilai : } 2 \\
\mathbf{\Delta}=\text { kuat } & \rightarrow \text { Nilai : } 3
\end{array}
$$

\begin{tabular}{|c|c|c|c|c|c|c|c|c|c|c|c|c|}
\hline \multirow{2}{*}{$\begin{array}{l}\text { Kebutuhan } \\
\text { dan } \\
\text { keinginan } \\
\text { Alumni }\end{array}$} & \multicolumn{12}{|c|}{ Perbaikan } \\
\hline & B1 & B2 & B3 & B4 & B5 & B6 & B7 & B8 & B9 & B10 & B11 & B12 \\
\hline A1 & $\Delta$ & $\Delta$ & $\Delta$ & $\varnothing$ & $\varnothing$ & $\varnothing$ & $\varnothing$ & $\varnothing$ & $\varnothing$ & $\Delta$ & $\varnothing$ & $\varnothing$ \\
\hline $\mathrm{A} 2$ & $\varnothing$ & $\Delta$ & $\varnothing$ & $\varnothing$ & a & $\Delta$ & $\varnothing$ & $\varnothing$ & $\varnothing$ & ! & $\varnothing$ & $\varnothing$ \\
\hline A4 & $\bar{\Delta}$ & $\bar{\Delta}$ & $\bullet$ & $\bar{\Delta}$ & $\bar{\Delta}$ & $\bar{\Delta}$ & - & $\square$ & $\varnothing$ & $\varnothing$ & $\varnothing$ & $\square$ \\
\hline A5 & • & $\bar{\Delta}$ & • & $\bar{\Delta}$ & $\bar{\Delta}$ & $\Delta$ & घ & - & $\varnothing$ & $\varnothing$ & $\varnothing$ & $\varnothing$ \\
\hline A6 & - & $\Delta$ & $\bullet$ & $\Delta$ & $\Delta$ & $\boldsymbol{\Delta}$ & $\varnothing$ & $\square$ & $\varnothing$ & $\varnothing$ & $\varnothing$ & $\varnothing$ \\
\hline A7 & $\varnothing$ & $\square$ & $\varnothing$ & $\varnothing$ & $\varnothing$ & $\boldsymbol{\Delta}$ & $\Delta$ & $\square$ & $\varnothing$ & $\varnothing$ & $\varnothing$ & $\varnothing$ \\
\hline Prioritas & 4 & 1 & 3 & 6 & 5 & 2 & 8 & 9 & 12 & 7 & 11 & 10 \\
\hline
\end{tabular}

Tabel 4. Matriks rumah mutu sederhana 
Prioritas perbaikan berdasarkan hasil perhitungan variabel hubungan antara kebutuhan dan keinginan alumni dengan perbaikan proses internal diperoleh nilai kontribusi terbesar yaitu 22. Dimana analisis ini dilakukan untuk mengetahui tingkat hubungan masing-masing harapan dan kebutuhan serta rumusan perbaikan untuk meningkatkan mutu kurikulum Pelatihan Penyusunan Renstra Kementerian ESDM.

\section{KESIMPULAN}

Hasil penelitian didapatkan bahwa harapan dan kebutuhan alumni pelatihan penyusunan renstra kementerian ESDM masih terdapat beberapa masukan sebagaimana tertera dalam tabel 2, dimana kemudian dikelompokkan dalam komponen kurikulum. Dari data tersebut maka dilakukan konfirmasi melalui wawancara (metode kualitatif), kepada tiga (3) orang widyaiswara yang berkompeten di bidangnya dan menghasilkan dua belas (12) perbaikan .

Berikutnya dari tingkat hubungan masingmasing harapan dan kebutuhan serta rumusan perbaikan untuk meningkatkan mutu kurikulum Pelatihan Penyusunan Renstra Kementerian ESDM, prioritas perbaikan berdasarkan hasil perhitungan variabel hubungan antara kebutuhan dan keinginan alumni dengan perbaikan proses internal diperoleh nilai kontribusi terbesar yaitu 22.

Rekomendasi yang dapat disampaikan sebagai berikut:

1. Perlu perbaikan kurikulum dengan melakukan evaluasi waktu pelatihan untuk mencapai tujuan pelatihan;

2.Perlu penambahan waktu praktik di bandingkan teori;

3. Perlu disiapkan studi kasus yang relevan di lingkungan Kementerian ESDM untuk menunjang praktik;

4. Perlu perencanaan komunikasi lebih baik dengan pihak lain yang tepat dalam melakukan visitasi;

5. Perlu dibuatkan pedoman visitasi untuk pelaksanaan visitasi supaya sesuai dengan tujuan pelatihan;

6. Perlu perbaikan fasilitas / sarana dan prasarana pelatihan secara menyeluruh.

Penelitian ini masih merupakan penelitian awal dan perlu penelitian lanjutan, sehingga di harapkan hasil penelitian ke depan dapat memberikan kontribusi maksimal bagi peningkatan mutu pelatihan dan juga untuk pengembangan pelatihan penyusunan renstra Kementerian ESDM. Sehingga akan dapat menghasilkan tenaga-tenaga profesional di lingkungan Kementerian ESDM yang mampu menyusun renstra dengan baik, bisa lebih optimal dan dapat mengena ke masyarakat melalui program-program strategisnya.

\section{DAFTAR PUSTAKA}

Abdul Majid. (2014). Strategi Pembelajaran. Bandung: PT Remaja Rosdakarya.

Abidin, Yunus, 2010, Strategi Membaca : Teori dan Pembelajarannya. Bandung : Rizqi Press.

Allen, W. C. (2006) 'Overview and Evolution of the ADDIE Training System', Advances in Developing Human Resources, 8(4), pp. 430-441. doi: 10.1177/1523422306292942.

Aytaç, A., \& Deniz, V. (2005). Quality Function Deployment in Education: A Curriculum Review. Quality \& Quantity, 39, 507-514.

Boonyanuwat, N., Suthummanon, S., Memongkol, N., \& Chaiprapat, S. (2008, MayJune). Application of Quality Function Deployment for Designing and Developing a Curriculum for Industrial Engineering at Prince of Songkla University. Songklanakarin Journal of Science and Technology, 30(3), 349353.

Cavaye, A.L.M. (1996). Case study research: a multi-faceted research approach for IS. Information Systems Journal, 6, 227-242.

Cohen, L. (1995). Quality Function Deployment, How to Make QFD Work for You (1st ed.). Massachusetts: Prentice Hall.

Cronholm, Stefan and Goldkuhl, Goran, 2003, Strategies for Information Systems Evaluation - Six Generic Types. The Electronic Journal Information Systems Evaluation. Volume 6 Issue 2 (2003), pp 65-74, [online]. Tersedia : http://www.ejise.com

De Bruyn, Arnaud., Lilien, Garry. (2008). A multistage model of word-of-mouth influence through viral marketing, Intern. J. of Research in Marketing 25, 151-163, Elsevier.

Hamalik, Oemar. 2007. Dasar-Dasar Pengembangan Kurikulum. Bandung: Remaja Rosdakarya.

Handoko, T. Hani Handoko . 2003 . Manajemen . Edisi 2. Penerbit BPFE Yogyakarta, Yogyakarta.

Ibrahim, \& Masitoh. 2011. Evaluasi Kurikulum dalam kurikulum dan pembelajaran. Jakarta : Tim Pengembangan MKDP, Rajawali Pers.

Linderman dkk., 2003, Six Sigma: A GoalTheoretic Perspective. Journal of Operations Management 21, 193203.

Martaleo, M., \& Simatupang, T. (2013). Evaluasi 
Rancangan Kurikulum dengan Quality Function Deployment. Prosiding Seminar Nasional Manajemen Teknologi XVII (hal. A.31.1-5). Surabaya: Program Studi MMTITS.

Robbins, P. Stephen dan Mary Coulter. 2010. Manajemen, diterjemahkan oleh Bob Sabran, Wibi Hardani. Erlangga:Jakarta.

Sukmadinata, Nana Syaodih. 1997. Pengembangan Kurikulum. PT Remaja Rosdakarya. Bandung

Sukmadinata, Nana Syaodih, 2008, Metode Penelitian Pendidikan, Bandung : PT. Remaja Rosdakarya.
Sukmadinata, Nana Syaodih, \& Erliana Syaodih, 2012, Kurikulum dan Pembelajaran Kompetensi, Bandung: PT. Refika Aditama.

Warsito, Hermawan. 1992. Pengantar Metodologi Penelitian. Jakarta: Gramedia Pustaka Utama.

Worthen, B.R., \& Sanders, J.R. (1981). Educational evaluation: Theory and practice. Ohio: Charles A. Jones Publishing Company.

UU Nomor 20 Tahun 2003, tentang Sistem Pendidikan Nasional.

Peraturan Pemerintah Republik Indonesia Nomor 19 Tahun 2005 tentang Standar Nasional Pendidikan. 